Original article

\title{
Effects of high temperature on body temperature and hormonal adjustments in piglets
}

\author{
Anne Collin, Maria-Joao VAZ, Jean LE DividicH* \\ Unité Mixte de Recherches sur le Veau et le Porc, Institut National de la Recherche Agronomique, \\ 35590 Saint-Gilles, France
}

(Received 25 May 2001; accepted 25 January 2002)

\begin{abstract}
Effects of a high $\left(33^{\circ} \mathrm{C}\right)$ or thermoneutral $\left(23^{\circ} \mathrm{C}\right)$ temperature on body temperature and endocrine parameters were studied in weaned piglets. Rectal and skin temperatures were measured in four ad libitum fed animals per temperature during three weeks. After this acclimation period, 11 blood samples were withdrawn on a 24-h period. Over the acclimation period, rectal and skin temperatures were 0.6 and $2.9{ }^{\circ} \mathrm{C}$ higher, respectively, at $33^{\circ} \mathrm{C}$ than at $23{ }^{\circ} \mathrm{C}(P<0.01)$, this change occurring from the 1 st day at 23 or $33^{\circ} \mathrm{C}$. A tendency of serum leptin concentrations to be lower after meals at $33{ }^{\circ} \mathrm{C}$ than at $23{ }^{\circ} \mathrm{C}$ was also displayed $(P=0.09)$. Plasmatic concentrations in Insulin-like growth factor I and thyroxine were decreased at $33{ }^{\circ} \mathrm{C}$ relative to $23{ }^{\circ} \mathrm{C}(P<0.01$ and $P<0.06$, respectively), and triiodothyronine concentrations tended to be lower at $33^{\circ} \mathrm{C}$ than at $23^{\circ} \mathrm{C}(P=0.1)$, which could account for the lower heat production and growth observed in pigs exposed to high temperatures.
\end{abstract}

piglet / heat exposure / body temperature / thyroid hormones / IGF-I

Résumé - Effets d'une température ambiante élevée sur la température corporelle et les ajustements hormonaux chez le porcelet sevré. Les effets d'une température ambiante élevée $\left(33^{\circ} \mathrm{C}\right)$ ou thermoneutre $\left(23^{\circ} \mathrm{C}\right)$ sur la température corporelle et le statut hormonal sont étudiés chez le porcelet sevré. Les températures rectale et cutanée sont mesurées sur 4 animaux par température, nourris à volonté et acclimatés à la température expérimentale pendant trois semaines. Après cette période, les paramètres sanguins sont mesurés sur 11 échantillons prélevés sur un nycthémère. Au cours de la période d'acclimatation, les températures rectale et cutanée sont rapidement supérieures à $33^{\circ} \mathrm{C}$ qu'à $23^{\circ} \mathrm{C}$, respectivement de 0,6 et $2,9^{\circ} \mathrm{C}(P<0,01)$. Les concentrations sériques en leptine tendent à être inférieures à $33^{\circ} \mathrm{C}$ à l'état nourri $(P=0,09)$. Les taux d'Insulin-like growth factor I et thyroxine plasmatiques sont plus faibles à 33 qu'à $23^{\circ} \mathrm{C}$ (respectivement $P<0,01$ et $P<0,06$ ), et les concentrations en triiodothyronine tendent à être inférieures à $33^{\circ} \mathrm{C}(P=0,1)$, en accord avec la production de chaleur et la croissance plus faible de ces animaux au chaud.

porcelet / chaleur / température corporelle / hormones thyroïdiennes / IGF-I

* Correspondence and reprints

E-mail: didi@st-gilles.rennes.inra.fr 


\section{INTRODUCTION}

Exposure of pigs to high ambient temperature induces a decrease in heat production, which is mainly achieved by a decrease in voluntary feed intake [5, 23, 27], resulting in a reduced growth and carcass fatness (for review, see [19]). These problems can occur currently in tropical countries, even in large production units, but also in temperate countries during summer temperature peaks, increasing the days to slaughter and production costs. Several studies indicate that both rectal and skin temperatures are increased in growing pigs $[11,17]$ and in lactating sows $[24,26]$ under high temperatures. In addition, the decrease in energy metabolism and feed intake may have effects on hormones involved in the regulation of thermogenesis (thyroid hormones) [9], growth (IGF-1) $[4,10]$ and feed intake (leptin) [3]. However, studies usually deal with single time-point measurements, and less data are available in young pigs [28]. Data on 24 hour-patterns of hormone concentrations, particularly with regard to leptin, are lacking.

The present experiment was therefore designed to determine the effects of exposure of piglets to ambient temperature of 23 or $33{ }^{\circ} \mathrm{C}$ on performance and to give information about the pattern of the rise in body temperature. Hormones implicated in the regulation of thermogenesis, growth and appetite were studied, with hormonal concentrations being measured over 24 hours, to enable a better understanding of time and feed intake-related modulations under high temperature.

\section{MATERIALS AND METHODS}

\subsection{Animals and experimental design}

The study was carried out in two identical environmental-controlled rooms. Two environmental temperatures were compared: one room was maintained at thermal neutrality $\left(23{ }^{\circ} \mathrm{C}\right)$ and the other was held at high temperature $\left(33^{\circ} \mathrm{C}\right)$.

Eight crossbred castrated (Large white $x$ Landrace) $\times$ Piétrain pigs with an initial body weight $(\mathrm{BW})$ of $15.4 \pm 1.6 \mathrm{~kg}$ were used in the study. They were allotted to temperature treatment on the basis of BW and litter origin. Following allocation, pigs were allowed a 7-d period for acclimation to the cages before the start of the experiment. During this period, environmental temperature was set at $25{ }^{\circ} \mathrm{C}$ in both rooms. On day (d) 8 and d 9, corresponding to the $1 \mathrm{st}$ and 2nd experimental days, respectively, the environmental temperature was gradually increased to $33{ }^{\circ} \mathrm{C}$ (two degrees per six hours), or decreased to $23{ }^{\circ} \mathrm{C}$. Thereafter, environmental temperature remained constant.

From the arrival in the temperature-controlled rooms, piglets were housed in individual wire cages $(1.0 \times 0.5 \mathrm{~m})$. They were fed ad libitum a standard pelleted diet providing $219 \mathrm{~g}$ crude protein, $26 \mathrm{~g}$ lipids, $27 \mathrm{~g}$ crude fibre and $11.08 \mathrm{MJ}$ net energy per kg diet (on as fed basis). Daily feed intake was determined from daily weighing of proposals and refusals. Rectal temperature was determined using a display thermometer (model BAT-12, Physitemp Bioblock, France) and skin temperature was determined using an infrared thermometer (THI 300, Tosco Japan Co, Osaka, Japan). Measurements of skin temperature were taken at the level of the interscapular region. Both temperatures were determined twice daily (between 0900 and 0930 a.m. and between 0300 and 0330 p.m.) during the first week and every two days (between 1000 and 1030 a.m.) thereafter. However, due to technical difficulties, skin temperature determinations started only on the 2 nd experimental day.

On the morning of the 22nd experimental day, a silastic catheter was inserted in a jugular vein under general anaesthesia using 
halothane inhalation. Daily feed allocation was offered in four meals at 0800 and 1100 a.m. and at 0300 and 0600 p.m. from day 22 onward, in an attempt to control meal times. On d 25, piglets were subjected to 11 blood samplings in 24 hours as indicated in Figure 3. On d 26, piglets were given their first morning meal and killed. Their liver, spleen, heart, thyroid gland, kidneys, adrenals, internal and external fat were removed and weighed.

\subsection{Blood analyses}

At each sampling time, two tubes were filled to get both plasma and serum. Blood was collected in an heparinised tube and centrifugated to obtain plasma, whereas an other sample was collected in a clean tube, clotted $12 \mathrm{~h}$ at $4{ }^{\circ} \mathrm{C}$ and the serum removed. Plasma concentrations in Insulin-like growth factor I (IGF-I) were measured by double antibody radioimmunoassays, validated [20] after extraction of IGFs binding proteins with ethanol-acid according to Daughaday et al. [8]. Thyroid hormones (triiodothyronine $\mathrm{T}_{3}$ and thyroxine $\mathrm{T}_{4}$ ) concentrations were determined by radioimmunoassay using commercial kits (ICN, Hyland Avenue, Costa Mesa, CA 92626, USA). Finally, serum leptin was determined using a commercial kit (multispecies radioimmunoassay; Linco Research, St. Charles, MO) validated on serum by Qian et al. [25]. The assay sensitivity was estimated as $90 \%$ of total binding and the intra-assay coefficient of variation $(\mathrm{CV})$ was $6 \%$. All measurements were run in the same assay to avoid inter-assay variation.

\subsection{Statistical analyses}

In an attempt to determine how fast rectal temperature $\left(\mathrm{RT},{ }^{\circ} \mathrm{C}\right)$ of pigs increases with the rise in environmental temperature, and to make a clear distinction between the periods during which RT increases and is stabilised, we looked for a "threshold day" i.e. the day of stabilisation of RT, in using a bilinear model:

$$
\begin{aligned}
\mathrm{RT}\left({ }^{\circ} \mathrm{C}\right)= & \mathrm{RT}_{0}+\mathrm{b}_{1} \times \mathrm{D}-\left(\mathrm{b}_{1}-\mathrm{b}_{2}\right) \times \mathrm{s} \times \mathrm{LN} \\
& (1+\exp ((\mathrm{D}-\mathrm{Dc}) / \mathrm{s}))
\end{aligned}
$$

where $\mathrm{D}$ was the experimental day (d), $\mathrm{RT}_{0}$ the rectal temperature $\left({ }^{\circ} \mathrm{C}\right)$ at $\mathrm{D}=0$, Dc the threshold day $(d), b_{1}$ the linear variation of rectal temperature $\left({ }^{\circ} \mathrm{C} \cdot \mathrm{d}^{-1}\right)$ before Dc and $b_{2}$ the linear variation of rectal temperature $\left({ }^{\circ} \mathrm{C} \cdot \mathrm{d}^{-1}\right)$ after Dc. The parameter s, similar to that used by Koops and Grossman [16], determines the smoothness of the transition around Dc. In the current study, s was fixed at 0.5 , which ensured a virtually instantaneous transition between both parts of the curve around Dc. The different parameters $\mathrm{t}, \mathrm{b}_{1}, \mathrm{~b}_{2}$ and Dc were estimated by NLIN procedure of SAS [33].

Data of skin and rectal temperatures after day 2 were analysed by the General Linear Model procedure of SAS [33]. Data from blood parameters at 23 and $33^{\circ} \mathrm{C}$ were also compared with ANOVA at each sampling time. Average concentrations of each hormone over the 24-h period of measurement were further determined by calculating the area under the curves with the trapezoidal technique. The overall effect of temperature was then tested by ANOVA. Weights of excised organs, glands and tissues were analysed by ANOVA [33].

\section{RESULTS}

The performance data recorded on intact animals (from d 1 to d 20) are summarised in Table I. On the whole, daily voluntary feed intake (VFI) and average daily gain were 42 and $39 \%$ lower $(P<0.01)$ at 33 than at $23{ }^{\circ} \mathrm{C}$, respectively, while feed to gain ratios were similar at both temperatures.

At killing, absolute weights of liver, heart, spleen, backfat and leaf fat were significantly lower at 33 than $23{ }^{\circ} \mathrm{C}$. However, this temperature effect was no longer 
Table I. Influence of ambient temperature $\left(23\right.$ or $\left.33^{\circ} \mathrm{C}\right)$ on performance and weights of several tissues and organs.

\begin{tabular}{|c|c|c|c|c|}
\hline & \multicolumn{2}{|c|}{ Temperature, ${ }^{\circ} \mathrm{C}$} & \multirow[b]{2}{*}{ RSD } & \multirow[b]{2}{*}{ Significance $^{\mathrm{a}}$} \\
\hline & 23 & 33 & & \\
\hline Number of observations & 4 & 4 & & \\
\hline Average body weight, $\mathrm{kg}^{\mathrm{b}}$ & 23.6 & 21.1 & 2.1 & \\
\hline Slaughter body weight, $\mathrm{kg}^{\mathrm{c}}$ & 35.0 & 28.0 & 2.2 & $\mathrm{~T}^{* *}$ \\
\hline Voluntary feed intake, $\mathrm{g} \cdot \mathrm{d}^{-1}$ & 1362 & 915 & 149 & $\mathrm{~T}^{* *}$ \\
\hline Average daily gain, $\mathrm{g} \cdot \mathrm{d}^{-1}$ & 794 & 488 & 48 & $\mathrm{~T} * *$ \\
\hline Feed to gain ratio & 1.71 & 1.88 & 0.20 & \\
\hline \multicolumn{5}{|c|}{ Weights of tissues and organs $(g)^{d}$} \\
\hline Liver & 830 & 633 & 69 & $\mathrm{~T}^{* *}$ \\
\hline Spleen & 55 & 39 & 9 & $\mathrm{~T}^{*}$ \\
\hline Heart & 163 & 136 & 8 & $\mathrm{~T}^{* *}$ \\
\hline Thyroid gland & 3.6 & 3.0 & 0.8 & \\
\hline Kidneys & 159 & 131 & 13 & $\mathrm{~T}^{*}$ \\
\hline Adrenal glands & 1.8 & 1.8 & 0.2 & \\
\hline Backfat & 982 & 654 & 158 & $\mathrm{~T}^{*}$ \\
\hline Leaf fat & 194 & 108 & 34 & $\mathrm{~T}^{*}$ \\
\hline Backfat + leaf fat & 1176 & 762 & 186 & $\mathrm{~T}^{*}$ \\
\hline
\end{tabular}

a $\mathrm{T}:$ temperature effect $; * P<0.05 ; * * P<0.01$

${ }^{\mathrm{b}}$ Mean body weight over the 20 days of acclimation.

${ }^{\mathrm{c}}$ Body weight on morning of day 26.

d Analysis of data expressed per kg of body weight did not show any significant effect of temperature, although means were always higher at $23^{\circ} \mathrm{C}$.

significant when weights of tissues or organs were expressed per kg of body weight. Environmental temperature had no significant effect on absolute and relative $\left(\cdot \mathrm{kg}^{-1} \mathrm{BW}\right)$ weights of thyroid and adrenal glands.

Reducing environmental temperature from 25 to $23{ }^{\circ} \mathrm{C}$ had no significant effect on rectal temperature (RT), which remained essentially constant over the experimental period (Fig. 1). However, skin temperature (ST) rose slightly from d 2 to $d 6$ and remained constant thereafter, plateauing at $36.0{ }^{\circ} \mathrm{C}$ (Fig. 2). In contrast, increasing the environmental temperature from 25 to $33{ }^{\circ} \mathrm{C}$ resulted in a dramatic increase in both rectal and skin temperatures. The equation relating RT to time during the experimental period was as follows:

$\mathrm{RT}\left({ }^{\circ} \mathrm{C}\right)=37.2+2.37 \mathrm{D}$

$$
-1.20 \mathrm{LN}\left(1+\mathrm{e}^{(\mathrm{D}-1.29) / 0.5}\right)
$$

where RT was rectal temperature $\left({ }^{\circ} \mathrm{C}\right)$ and D was the experimental day (from 1 to 17).

Rectal temperature increased from 38.7 to $40.2{ }^{\circ} \mathrm{C}$ within the period of temperature increase in the climate room (d 1 and 2$)$, and tended to decrease by $0.03{ }^{\circ} \mathrm{C} \cdot \mathrm{d}^{-1}$ thereafter. In average on the whole experimental period (except days 1 and 2), piglets RT was $0.6^{\circ} \mathrm{C}$ higher at 33 than at $23^{\circ} \mathrm{C}(P<0.01)$. Skin temperature, determined only from day 2 , remained unchanged during the observation period, plateauing at $38.9{ }^{\circ} \mathrm{C}$. It was in average $2.9^{\circ} \mathrm{C}$ higher at 33 than at $23{ }^{\circ} \mathrm{C}(P<0.01)$.

Patterns of plasma $\mathrm{T}_{3}, \mathrm{~T}_{4}$ and IGF-1 and serum leptin concentrations during the $24-\mathrm{h}$ period of measurement are presented in Figure 3. At both environmental temperatures, plasma $\mathrm{T}_{3}, \mathrm{~T}_{4}$ and IGF-1 concentrations remained essentially constant over a 24 hour 
Figure 1. Rectal temperature $\left(\mathrm{RT},{ }^{\circ} \mathrm{C}, \pm\right.$ S.E. $)$ profiles over the acclimation period at $23{ }^{\circ} \mathrm{C}(\boldsymbol{\square})$ or $33{ }^{\circ} \mathrm{C}(\mathbf{)})$. Data at $33^{\circ} \mathrm{C}$ was analysed by a bilinear model ( $\longrightarrow$ ) and mean rectal temperature at $23{ }^{\circ} \mathrm{C}(---)$ was $\mathrm{RT}=$ $39.4{ }^{\circ} \mathrm{C} \pm 0.2{ }^{\circ} \mathrm{C}$.

Figure 2. Skin temperature $\left(\mathrm{ST},{ }^{\circ} \mathrm{C}, \pm \mathrm{S}\right.$.E.) profiles over the acclimation period at $23{ }^{\circ} \mathrm{C}(\boldsymbol{\square})$ or $33{ }^{\circ} \mathrm{C}(\mathbf{O})$.
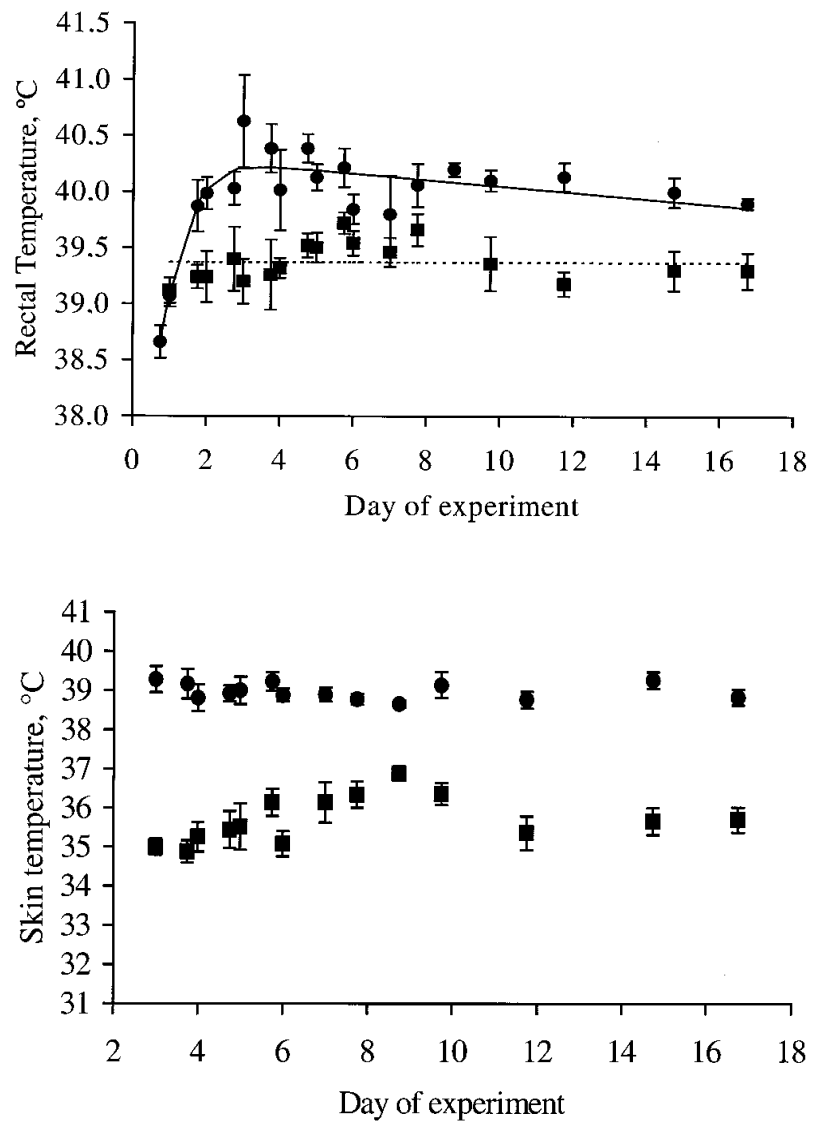

period, with overall concentrations (area under the curve) being lower at $33{ }^{\circ} \mathrm{C}$ than at $23{ }^{\circ} \mathrm{C}$ for $\mathrm{T}_{4}(P<0.06)$ and IGF-1 $(P<0.01)$ in the high temperature group. However, $\mathrm{T}_{3}$ concentrations were significantly lower at $33{ }^{\circ} \mathrm{C}$ at time points 90 and 270 . At both 23 and $33{ }^{\circ} \mathrm{C}$, initial and final serum concentrations of leptin were similar, averaging 1.7 and $1.8 \mathrm{ng} \cdot \mathrm{mL}^{-1}$, respectively. At $23^{\circ} \mathrm{C}$, serum leptin concentrations tended to be higher $(P<0.10)$ than the initial level from 0400 to 1100 p.m. (times 510 to $930 \mathrm{~min}$ ), whereas at $33{ }^{\circ} \mathrm{C}$, concentrations remained essentially constant over the period of measurement. The area under the curve for leptin concentrations was significantly different between 23 and $33{ }^{\circ} \mathrm{C}(P=0.05)$ between time-points 270 and 930 min. Despite a low number of animals per treatment $(n=4)$, leptin concentrations were significantly lower at 33 than at $23{ }^{\circ} \mathrm{C}$ at 0500 p.m. and 1100 p.m. (times 570 and $930 \mathrm{~min}$; $P=0.02$ and $P=0.01$, respectively).

\section{DISCUSSION}

The present study provides new information about, on the one hand, the very fast response of pigs body temperature when subjected to increasing ambient temperature, and on the other hand, on the hormonal (especially leptin) concentrations 24-h patterns under both treatments, which suggest heat-induced hormonal adjustments, 

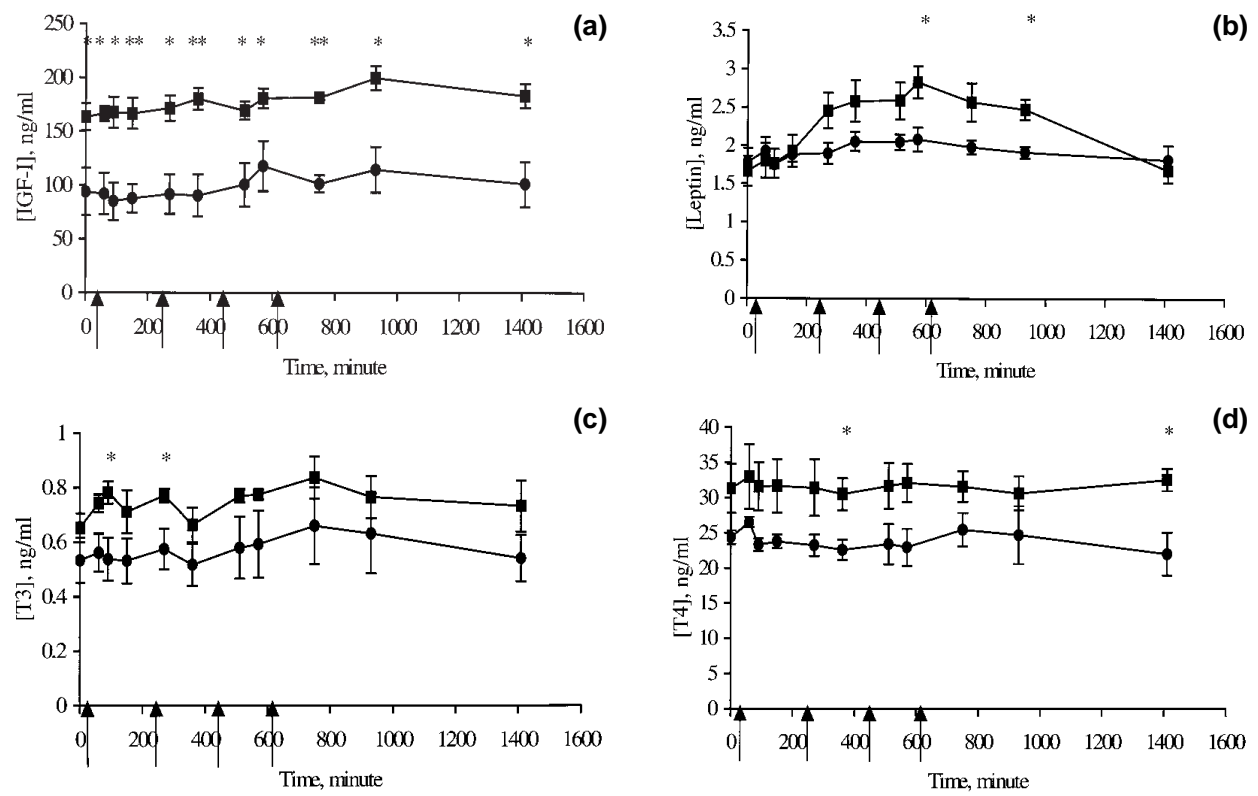

Figure 3. Circulating concentrations $\left( \pm\right.$ S.E.) of IGF-I (a), leptin (b), triiodothyronine $\left(\mathrm{T}_{3}, \mathbf{c}\right)$ andthyroxine $\left(\mathrm{T}_{4}, \mathbf{d}\right)$ over a 24 -h period in pigs acclimated to $23{ }^{\circ} \mathrm{C}(\boldsymbol{\square})$ or $33{ }^{\circ} \mathrm{C}(\mathbf{\bullet})$. Meal times are indicated by arrows at the bottom of graphs. Time zero min corresponds to $0730 \mathrm{a} . \mathrm{m}$. and time $1410 \mathrm{~min}$ to $0700 \mathrm{a}$ a.m. the following day. Blood samples were taken at 0730, 0830, 0900, 1000 and 1200 a.m., 0130, 0400, 0500, 0800 and 1100 p.m., and 0700 a.m. the following day.

sometimes dependent on the feeding status of the animals.

First, the observed overall effects of exposure of piglets to high environmental temperature on voluntary feed intake and, hence, on daily weight gain, are in accordance with previous data $[5,31,34]$. Prolonged exposure to high environmental temperature is reported to enhance fat accumulation at internal sites (leaf fat, viscera) at the expense of external sites (backfat) $[15,18,31]$ and to have a negative effect on relative weights of liver, heart, kidneys and thyroid and adrenal glands in young growing (10-30 kg) or finishing (60-100 kg) pigs $[13,31,34]$. In the present experiment, such effects were not observed likely because of the short duration of the trial.

In addition, exposure of piglets to high environmental temperature affected plasma
$\mathrm{T}_{4}$ and IGF-1 concentrations and, but to a lesser extent, $\mathrm{T}_{3}$ and leptin concentrations. There is a possibility that hemodilution caused by high temperature could have an effect on blood hormone concentrations. However, to our knowledge, data on blood volume or hematocrit change during heat exposure are scarce. Thyroid hormones, especially $\mathrm{T}_{3}$, are known to be thermogenic. They stimulate oxidative phosphorylation and ATP exportation $[12,14]$ and mitochondria biogenesis [9]. Their decreased concentrations at high temperature $[21,32]$ are consistent with the reduction in heat production in observed in such conditions [23, 27]. However, in our study, only plasma $\mathrm{T}_{4}$ concentrations were significantly lowered at high temperature. Both the small number of data and the rather high individual variation could account for the non-significant decrease in $\mathrm{T}_{3}$ concentrations at high temperature. 
Similarly to $\mathrm{T}_{4}$, concentrations of plasma IGF-1 were reduced at high temperature. Under ad libitum feeding conditions, concentrations of plasma IGF-1 are also reduced in lactating sows held at high temperature [22], whereas concentrations are not different in sows under paired feeding conditions [24]. Our results are consistent with the fact that concentrations of IGF-1 are mainly dependant on nutritional status of the pig [4], with levels being closely related to the energy intake and hence to growth rate [10].

Leptin is described as a regulator of food intake and energy balance [29]. In our study, only tendency to lower concentrations of leptin at $33{ }^{\circ} \mathrm{C}$ than at $23{ }^{\circ} \mathrm{C}$ were observed in the fed state, except for two sampling times. However, leptin concentrations at $23{ }^{\circ} \mathrm{C}$ tended to be higher in the fed state than in the fasted state. An increase in leptin concentrations after a meal is also reported in rodents, but not in humans [6]. In our conditions, leptin response to feeding could be lowered at high temperature. Several hypotheses could explain this observation: the feeding stimulus could be too low to enable leptin concentrations to rise after a meal, which is consistent with the decrease in leptin expression and concentration reported in underfed ruminants $[1,3,35]$. Moreover, a decrease in insulin concentrations related to the decrease in feed intake is reported at high temperature in piglets [30], which also could account for the lack of effect of the meal on leptin concentrations. Finally, Cameron et al. [2] indicate that leptin concentrations are more correlated to the pig adiposity than to its feed intake. As a consequence, the tendency of postprandial leptin concentrations to be decreased at high temperatures could be associated with the decrease in adipose tissue mass in our heatacclimated piglets.

A striking result of our study is the rapid increase in body temperature as indicated by the increases in RT and ST at high temperature. The rise in ST agrees well with the increased blood flow to the skin [5] and could be a specific response to heat exposure, contributing to maintain a gradient between skin and ambient temperature and hence to maintain sensible heat loss [7]. An increase in skin and rectal temperatures in response to exposure to high ambient temperature is also reported in growing [11, 17] and in lactating sows [24, 26]. These last authors reported that RT of lactating sows starts to rise at environmental temperature higher than $25^{\circ} \mathrm{C}$, with the rate of increase amounting $0.09{ }^{\circ} \mathrm{C}$ per one ${ }^{\circ} \mathrm{C}$ temperature rise within the temperature range of $25-29^{\circ} \mathrm{C}$. Corresponding rate of increase in our piglets is estimated to $0.08{ }^{\circ} \mathrm{C}$ between 25 and $33{ }^{\circ} \mathrm{C}$. However it is noticeable that the short-term response of RT and ST is concomitant to the rise in ambient temperature in good agreement with the data of Rafaï [28]. This would suggest that ambient temperatures higher than $25^{\circ} \mathrm{C}$ are hyperthermal for piglets weighing approximately $22 \mathrm{~kg}$ in close agreement with our previous data [5]. In heat-exposed piglets, the physiological meaning of a possible longer-term slight decrease in rectal temperature remains to be explored, in relation to mechanisms of acclimation to high temperature.

\section{CONCLUSION}

Our results suggest that rectal and skin temperatures rise within two days as ambient temperature rises above $25^{\circ} \mathrm{C}$, whereas feed consumption decreases within five days of exposure. Acclimation of piglets to high temperatures was associated with decreases in plasma thyroid hormones and IGF-I, whereas leptin serum concentrations tended to be decreased at high temperature only in the fed state.

\section{ACKNOWLEDGEMENTS}

The authors thank J. Gauthier and H. Renoult for animal care, and F. Thomas, F. Giovanni, M. Fillaut and A.M. Mounier for technical 
assistance. We are grateful to A. Prunier and P. Herpin for helpful discussions and suggestions. This work was supported by grants from the Institut National de la Recherche Agronomique, Tours and Rennes.

\section{REFERENCES}

[1] Bocquier F., Bonnet M., Faulconnier Y., GuerreMillo M., Martin P., Chilliard Y., Effects of photoperiod and feeding level on adipose tissue metabolic activity and leptin synthesis in the ovariectomized ewe, Reprod. Nutr. Dev. 38 (1998) 489-498.

[2] Cameron N.D., Penman J.C., McCullough E., Serum leptin concentration in pigs selected for high or low daily food intake, Genet. Res. 75 (2000) 209-213.

[3] Chilliard Y., Bocquier F., Delevaud C., Faulconnier Y., Bonnet M., Guerre-Millo M., Martin P., Ferlay A., La leptine chez le ruminant. Facteurs de variation physiologiques et nutritionnels, INRA Prod. Anim. 12 (1999) 225-237.

[4] Clemmons D.R., Underwood L.E., Nutritional regulation of IGF-I and IGF binding proteins, Annu. Rev. Nutr. 11 (1991) 393-412.

[5] Collin A., van Milgen J., Le Dividich J., Modelling the effect of high, constant temperature on feed intake in young growing pigs, Anim. Sci. 72 (2001) 519-527.

[6] Considine R.V., Caro J.F., Leptin and the regulation of body weight, Int. J. Biochem. Cell Biol. 29 (1997) 1255-1272.

[7] Curtis S.E., Environmental managements in animals agriculture, Ames: Iowa, University Press, 1983.

[8] Daughaday W.H., Mariz I.K., Blethen S.L., Inhibition of access of bound somatomedin to membrane receptor and immunobinding sites: A comparison of radioreceptor and radioimmuno-assay of somatomedin in native and acid-ethanolextracted serum, J. Clin. Endocrinol. Metab. 51 (1980) 781-788.

[9] Dauncey M.J., Thyroid hormones and thermogenesis, Proc. Nutr. Soc. 49 (1990) 203-215.

[10] Dauncey M.J., Burton K.A., Tivey D.R., Nutritional modulation of insulin-like growth factor-I expression in early postnatal piglets, Pediatr. Res. 36 (1994) 77-84.

[11] Giles L.R., Energy expenditure of growing pigs at high ambient temperatures, Ph.D. thesis, University of Sidney, 1992.

[12] Gregory R.B., Berry M.N., The administration of triiodothyronine to rats results in a lowering of the mitochondrial membrane potential in isolated hepatocytes, Biochim. Biophys. Acta 1133 (1991) 89-94.
[13] Heath M., The effects of rearing-temperature on body conformation and organ size in young pigs, Comp. Biochem. Physiol. B 77 (1984) 63-72.

[14] Hoch F.L., Adenine nucleotide translocation in liver mitochondria of hypothyroid rats, Archiv. Biochem. Biophys. 178 (1977) 535-545.

[15] Katsumata M., Kaji Y., Saitoh M., Growth and carcass fatness responses of finishing pigs to dietary fat supplementation at a high ambient temperature, Anim. Sci. 62 (1996) 591-598.

[16] Koops W.J., Grossman M., Multiphasic allometry, Growth Dev. Aging 57 (1993) 183-192.

[17] Korthals R.L., Hahn G.L., Eigenberg R.A., Nienaber J.A., Swine feeding behavior and body temperature in response to an extended stepped temperature increase, ASAE Livest. Environ. V (1), Proceedings of the 5th International Symposium, 1997, pp. 781-788.

[18] Le Dividich J., Noblet J., Bikawa T., Effect of environmental temperature and dietary energy concentration on the performance and carcass characteristics of growing-finishing swine fed to equal rate of gain, Livest. Prod. Sci. 17 (1987) 235-246.

[19] Le Dividich J., Noblet J., Herpin P., Quiniou N., Thermoregulation, in: Wiseman J.J., Varley M.A., Chadwick J.P. (Eds.), Progress in Pig Science, Nottingham University Press, 1998, pp. 229-264.

[20] Louveau I., Combes S., Cochard A., Bonneau M., Developmental changes in insulin-like growth factor-I (IGF-I) receptor levels and plasma IGF-I concentrations in Large White and Meishan pigs, Genet. Comp. Endocrinol. 104 (1996) 29-36.

[21] Macari M., Zuim S.M.F., Secato E.R., Guerreiro J.R., Effects of ambient temperature and thyroid hormones on food intake by pigs, Physiol. Behav. 36 (1986) 1035-1039.

[22] Messias de Bragança M., Prunier A., Effects of low feed intake and hot environment on plasma profiles of glucose, nonesterified fatty acids, insulin, glucagon, and IGF-I in lactating sows, Domest. Anim. Endocrinol. 16 (1999) 89-101.

[23] Nienaber J.A., Hahn G.L., Heat production and feed intake of ad-libitum-fed growing swine as affected by temperature, ASAE Paper No. 82-4065, St Joseph, Michigan, 1982.

[24] Prunier A., Messias de Bragança M., Le Dividich J., Influence of high ambient temperature on lactational performance of sows, Livest. Prod. Sci. 52 (1997) 123-134.

[25] Qian H., Barb C.R., Compton M.M., Hausman G.J., Azain M.J., Kraeling R.R., Baile C.A., Leptin mRNA expression and serum leptin concentrations as influenced by age, weight and oestradiol in pigs, Domest. Anim. Endocrinol. 16 (1999) 135-143. 
[26] Quiniou N., Noblet J., Influence of high ambient temperatures on performance of multiparous lactating sows, J. Anim. Sci. 77 (1999) 2124-2134.

[27] Quiniou N., Noblet J., van Milgen J., Dubois S., Modelling heat production and energy balance in group-housed growing pigs exposed to cold or hot ambient temperatures, Br. J. Nutr. 85 (2001) 97-106.

[28] Rafaï P., Influence of the dry and humid air on the weight gain and food-conversion of fattening pigs, Különlenyomat a Kisérletügyi Közlemények LXVII/B, 1 (1974) 41-56.

[29] Ramsay T.G., Leptin: A regulator of feed intake and physiology in swine, in: Cranwell P.D. (Ed.), Manipulating Pig Production VII, Australian Pig Science Association, 1999, pp. 157-170.

[30] Rinaldo D., Influence de la température ambiante sur le métabolisme énergétique et tissulaire et le besoin en lysine du porc en croissance. Mise en évidence de l'intérêt d'une température élevée Thèse de doctorat de l'Université de Rennes I, 1989.
[31] Rinaldo D., Le Dividich J., Assessment of optimal temperature for performance and chemical body composition of growing pigs, Livest. Prod. Sci. 29 (1991) 61-75.

[32] Rinaldo D., Le Dividich J., Effects of warm exposure on adipose tissue and muscle metabolism in growing pigs, Comp. Biochem. Physiol. A 100 (1991) 995-1002.

[33] Statistical Analysis Systems Institute SAS User's guide: Statistics. Statistical Analysis Systems Institute Inc., Cary, NC, 1990.

[34] Sugahara M., Baker D.H., Harmon B.G., Jensen A.H., Effect of ambient temperature on performance and carcass development ,in young swine, J. Anim. Sci. 31 (1970) 59-62.

[35] Tsuchiya T., Nagao Y., Ozawa A., Matsumoto M., Sugahara K., Kubo T., Kato H., Decrease of the obese gene expression in bovine subcutaneous adipose tissue by fasting, Biosci. Biotechnol. Biochem. 62 (1998) 2068-2069. 